C JBSSR/AIM, 2018, ISSN: 2542-2812.

\title{
An Analysis of Security Market Growth and Individuals' Investment Decision
}

\author{
Dipika Joshi ${ }^{1}$
}

\begin{abstract}
The purpose of this study is to analyze the growth of Security Market from FY 2005/06 to FY 2016/17 and to determine the most influencing factor that drive investment decision. The security market growth indicators taken are Market Size and Market Liquidity. To examine the relationship between Investment Decision and influencing factors, factors such as Advocate Recommendation, Personal Financial Needs, Accounting Information, Firm's Image and Neutral Information are taken into consideration. For this study, data are collected both from primary as well as secondary sources. To analyze the growth of stock market, secondary data have been obtained from annual publication of NEPSE, SEBON, MOF etc and statistical analysis like Ratio Analysis (such as MCR and ML), Growth Analysis and Correlation have been applied. For the study of investment decision, primary data have been collected with the sample size of 200. T-test has been applied to examine the relationship between investment decision and influencing factors. The result shows that Nepalese capital market has erratic trend during study period. It implies that capital market is immature and investors are not motivated to invest in the companies. It is also not deniable that the capital market has developed compared to FY 2005/06. Furthermore, Nepalese investors mostly consider firm's reputation in the industry and opinion of firms' majority of stockholder before investing in any stock.
\end{abstract}

Keywords: stock market development, growth analysis, investment decision, firm's reputation

\section{Introduction}

Capital market is defined as the market where medium to long-term finance can be raised (Akingbohungbe, 1996). Similarly, capital market helps flow of nonproductive small savings spread among the people to the productive sector through mobilization. Capital market establishes working relationships between the people engaged in saving, mobilization, and investing capital. A capital Market plays vital role in the economy as it mobilizes the unproductive financial resource in productive sectors of the economy (Nepal Rastra Bank, 2012). It can be classified as Primary capital market and secondary capital market. Primary market is a

1 Ms. Joshi is MBA graduate of Ace Institute of Management, Affiliated to Pokhara University.

Corresponding Email: dipika.joshi33@gmail.com 
market in which new issues of a security, such as a bond and stock are sold to initial buyers by corporation or government agency (Mishkin \& Eakins, 2012). On the contrary, secondary market consists of exchanges and over-the counter markets where securities are bought and sold after their issuance in the primary market (Mishkin \& Eakins, 2012). It provides liquidity to these instruments, through trading and settlement on the stock exchanges.

Development of capital market is must for a sound industrial development of the country. The history of stock market in Nepal started with the establishment of Securities Exchange Centre (SEC) in 1976 with an objective of facilitating and promoting the growth of capital market. However, the organized and full-fledged stock market began with the conversion of Securities Exchange Centre into Nepal Stock Exchange (NEPSE) Limited in 1993. Nepalese capital market has witnessed several new practices in past decades. During this period a several initial public offering (IPOs) were made. Many new stocks have been listed in NEPSE. The listing of more agro-based industries like Dairy Development Corporation, telecom and hydropower have made the share market more reflective of economic growth. Moreover, changes on the regulations and infrastructure, establishment of Central Depository System (CDS), Credit Rating Agency (CRA), and addition of more mutual funds have definitely changed the scenario. Having the sensitive nature, economic, social, and political interference would directly affect capital market. Development of capital market in any country and its effective growth are depended upon the aggregate economic condition, saving and investment opportunity etc.

Investment in stock market has recently gained popularity in developing countries like Nepal due to its significant growth. An investor can receive returns from stocks when prices of stocks go up over time or when dividends are paid (Mishkin $\&$ Eakin, 2007). Hence, investors consider various factors such as accounting information, Firms' image, Neutral information and many more before making investment decision. There is no doubt that investors are responsible for not having self-control, self-judgment in the choice of securities for investment. Thus having lack of adequate knowledge about the securities of certain companies, investors are haphazardly investing in shares. Therefore, it is necessary to do some research on Nepalese capital market in changing situation to analyze the growth of capital market and the factors influencing the individual investors to invest in capital market. Well it is not deniable that Nepal is least developed country (UNCTAD, 2011), however, the corrective approach towards capital market had helped it to explore. To sum up, this study tries to address the capital market development since FY 2005/06; and the most influencing factors in investment decision.

The remaining part of the paper is organized as follows; the second section includes review of past literature on secondary capital market and investment 
decision. The third section deals with the model and methods. The fourth section discusses about the analysis of data and its presentation and the fifth deals with the concluding remarks.

\section{Literature Review}

\subsection{Review on Secondary Capital Market}

Capital market consists of share market and debt market, therefore, development of stock market reflects the development of capital market. Stock Market is the catalyst for enhancing the operations of the entire domestic financial system and the Capital Market in particular (Obiakor \& Okwu, 2011). Capital markets are a vital part of the financial and economic development of a country. This is the reason several attempts have been made by previous researchers to link the development of capital market with the economy (Kolapo \& Adaramola, 2012). Numerous researches have explained that capital market is strongly linked with economic growth. Hence, gross domestic product (GDP) is mostly used as an indicator. Obiakor and Okwu (2011) found that development of capital market leads to economic growth. Similarly, it is found that capital market development has positive significant impact on economic growth. It indicates a positive correlation between capital market development and economic growth, as stock market is part of the capital market, it plays significant part in development of capital market (Baker et al., 2006). Blackburn et al. (2005) mentioned that there is a positive correlation between stock market development and economic growth under the assumption that for levels of GDP per capita higher than a certain threshold of the information costs become lower than bankruptcy costs, determining the development of capital markets.

Studies suggested positive relationship between market liquidity and economic growth. In a cross-country regression, (Naes et al., 2010) found a significant positive correlation between stock market liquidity and current and future rates of economic growth, after controlling for economic and political factors. El-Wassal (2013), concluded that stock market development is a difficult, complex, multi-faceted, and long-term process and it cannot be developed in the absence of a financial system. Moreover, private sectors are responsible for the development of a stock market but at the same time the role of the government too cannot be overlooked. However, Hoque and Yakob (2017) examine the stock market development and economic growth nexus and moderating role of foreign capital inflows and exchange rate on the relationship between stock market development and economic growth of Malaysia during 1981-2016. They observe unidirectional effects of stock market development to Malaysian economic growth and there is a long run association between stock market development and economic growth. Further in the short run and long run, stock market promotes the economic growth of Malaysia. 
In Nepalese context, Bist (2017) examined the empirical relationship between stock market development and economic growth in Nepal over the period of 22 years from 1993 to 2014 . Their findings indicate that market capitalization has a significant positive impact on the economic growth in both long as well as in short run in Nepal. But, inflation has negative and significant impact on GDP per capita in long as well as in short run. They also found unidirectional causality runs from stock market development to economic growth in Nepal. Similarly, Gurung (2004) revealed that NEPSE index growth rate was very low and highly fluctuating that indicates poor performance of public limited companies listed in stock exchange. Such erratic trend in the value of market capitalization and its low contribution to GDP indicated the poor and immature capital market, de-motivation in investment in the companies, and downward trend of economy during the study period.

\subsection{Review on Investment Decision}

Investment decision plays crucial role for the development and systematic functioning of any organization. Various contextual factors like accounting information, firm image, expert advice, neutral information, personal financial needs etc. have a close link with Individual Investment Decision Making (Vijaya, 2014). For individual investors accounting information is the most influencing factor whereas neutral information is the least influencing factor while making investment decisions (Dharmaja et al., 2012). Merikas et al. (2004) partially supported this fact and stated that accounting information has significant influence whereas personal financial needs have least influence. Bashir et al. (2013) also concluded that accounting information highly affect the investment decision of Pakistani investors, whereas, advocate recommendation was the least influencing variable.

Studies also revealed the relationship between behavioral and demographic factors and financial literacy. Al-Tamimi et al. (2006) found that the most influencing factor is religious reasons and the least affecting factor is rumors. Similarly, Abdeldayem (2016) in his paper came up with similar conclusion. The study revealed that the financial literacy level of the Bahraini Investors is found to be low and women have lower financial literacy than men. It also concluded that financial literacy is highly correlated with education. Lodhi (2014), concluded that investors can lower the information asymmetry if they have financial literacy and accounting. Lower information asymmetry motivates investors to invest in risky instruments. With increase in age and experience, investors desire a stable income i.e. dividend return rather than capital gain.

There is some of the most and least influencing factors in investment decision. Jagongo and Mutswenje (2014) revealed that reputation of the firm, firm's status in 
industry, expected corporate earnings, profit and condition of statement, past performance firms stock, price per share, feeling on the economy and expected dividend by investors are the most influencing factors. Similarly, Obamuyi (2013) also came with the similar conclusion. According to the study, the most influencing factors in order of importance are past performance of the company's stock, expected stock split/capital increases/bonus, dividend policy, expected corporate earnings and the fifth influencing factor is get-rich quick. The study also indicated religions, rumors, loyalty to the company's products/services, opinions of members of the family and expected losses in other investments as the five least influencing factors on investment decision. These studies revealed that the impact of influencing factor on investment decision differs from investor to investors.

The Factors like influence of people's opinion (friends or family), past performance of the company, accounting information, confidence (over or under) etc. were found to have significant impact on the investors' behavior' across different countries; but factors like Stock marketability, diversification purpose, perceived ethics of the firm, etc. were found to be uncommon in various studies conducted across different countries (Safi, 2014). Khan et al. (2015) found that investment decisions are greatly impacted by the motivational factors i.e. industry attractiveness, historical data, expected dividends, financial indicators, loss minimization, and chances of capital gain.

In Nepalese case, Adhikari (2010) observed that Nepalese investors invested in shares for both financial and non-financial reasons. Similarly, Kadariya (2012) analyzed the market reactions to tangible information and intangible information in Nepalese stock market. The findings revealed that Dividends, earnings, number of equity, book-to-market ratio and political party led government are the top five most important factors for investment decisions.

\section{Methodology}

\subsection{The Conceptual Framework}

Obiakor and Okwu (2011) had found that development of capital market has positive relation with economic growth. In simple, the economic growth can be defined as capital market development. Market capitalization has been widely used in the literature as a stable measure of stock market development for two reasons. First, it is a measure of stock market size, which is positively correlated with the ability to mobilize capital and diversify risk. Second, it is presumed to include companies' past retained profits and future growth prospects so that a higher ratio to GDP can signify growth prospects as well as stock market development (Levine \& Zervos, 1998; Rajan \& Zingales, 2003). Gurung (2004) discovered that the stock market growth of Nepal can be measured through Growth analysis of Number of 
Listed and Traded Securities, Number of Transaction and Annual Turnover, Paid up Value and Market capitalization etc.

Al-Tamimi (2006) suggested that expected corporate earnings, get rich quick, stock marketability, past performance of the firm's stock, government holdings and the creation of the organized financial markets to be the most influencing factors on the UAE investor behavior. Similarly, Akbar et al. (2016) proved that advocate recommendations, self-image/firm image coincidence, neutral information have positive significant relationship with individual investor investment decision whereas, the study did not find any evidence on relationship between accounting information, classical wealth maximization and personal financial needs.

The overall conceptual framework for the stock market growth and investment decision are presented in figure 1 as:

Figure 1: Conceptual Framework

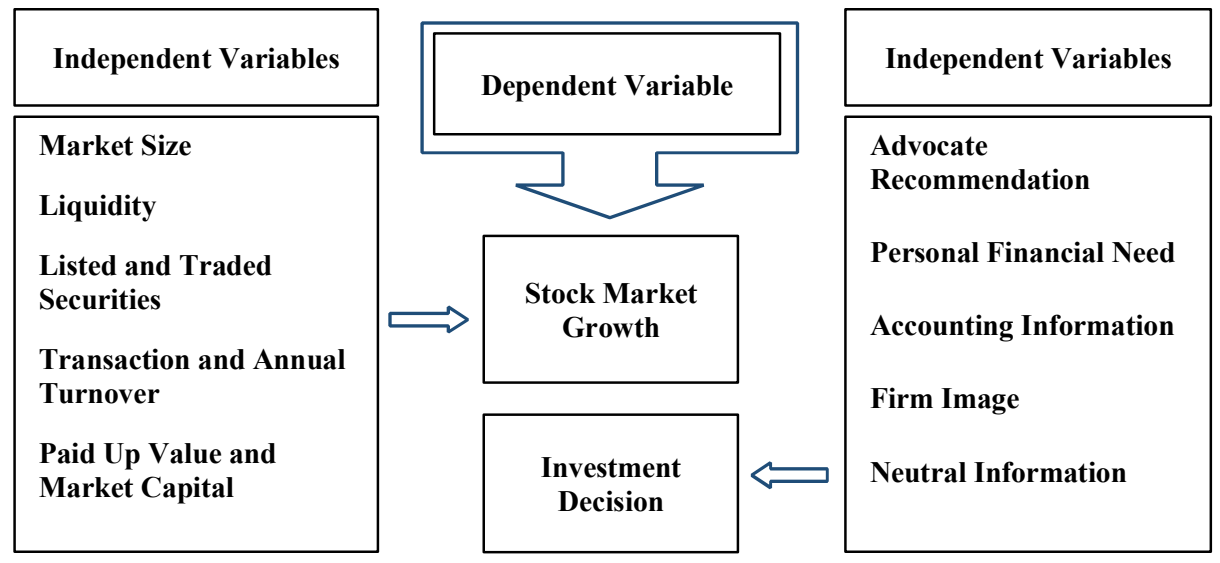

For the first model, dependent variable is stock market development. There are two main indicators of stock market size: market capitalization and the number of listed companies. A common indicator for assessing stock market size is Market capitalization/GDP, which equals the market value of listed shares divided by the relevant GDP. A comprehensive measure of liquidity would quantify all the costs associated with trading, including the time cost and the uncertainty of finding a counterpart and finalizing the transaction and turnover ratio. Traded value is a volume-based indicator. It measures the organized trading of shares as a percentage of national output and therefore should positively reflect stock market liquidity on an economy-wide basis. Turnover ratio gives an indicator of the number of times 
the outstanding volume of shares changes hands. Turnover ratio equals the value of total shares traded divided by market capitalization.

This study attempts to measure following hypothesis:

$\mathrm{H}_{1}$ : Secondary Market has not developed since 2005/06.

The dependent variable in the second model is individual investor's investment decision in NEPSE. Among the explanatory variables, Advocated Recommendation means the advice and suggestions given by the second party to the investors. Personal Financial Needs are directed by the risk appetite of the investors, their opinion, expectations and many more. Investors are primarily concerned with expectations about the future, considering earnings projection and historical data to be of high interest to investors. The investment decisions are influenced by selective information disclosures that are intended to promote a positive or negative firm image. The investors appear to under react to prior information as well as to information conveyed by the event, leading to different patterns.

This study attempts to measure following hypothesis:

$\mathrm{HO}_{2}$ : There is no significant relationship between advocate information and investment decisions.

$\mathrm{HO}_{3}$ : There is no significant relationship between personal financial needs and investment decisions.

$\mathrm{HO}_{4}$ : There is no significant relationship between accounting information and investment decisions.

$\mathrm{H}_{5}$ : There is no significant relationship between firm's image and investment decisions.

$\mathrm{H0}_{6}$ : There is no significant relationship between neutral information and investment decisions.

\subsection{Study Area and Data}

For this study, explanatory research design is used to obtain information concerning the current status of the phenomena. This study based on both secondary as well as primary data collected from different sources. The secondary data includes time series data from 2005/06 to 2016/17. 10 years' time series data from the year 2005/06-20016/17 have been collected from various reports and article published by Finance Ministry of Nepal and Nepal Rastra bank to analyze the growth of secondary capital market. 
For primary data collection, purposive sampling under non-probability sampling method was used. The study area coverage of primary research is inside Kathmandu Valley. All the respondents for this study are the individual investors that hold at least one stock. Primary data are collected through the questionnaire distributed to selected investors from family, friends working in various sectors and investors in NEPSE. Total 200 responses were collected. Before actual survey, a pilot study of 50 respondents is conducted and Cronbach's alpha test was conducted to check validity and reliability.

For the data analysis, inferential analysis like Growth Analysis, Correlation, Regression and Dw autocorrelation test are done, to confirm that there is no correlation between error data generated by regression line, with the help of Ms Excel which capture secondary data analysis. The Durbin Watson test for autocorrelation test indicates that there is no autocorrelation.

Karl Pearson's Coefficient Co-relation: Number of traded and listed companies (Gurung, 2004) have been tested using Karl Pearson's coefficient co-relation.

$$
r=\frac{n \sum X Y-\sum X \sum Y}{\sqrt{\left(n \sum X^{2}\right)-\left(\sum X\right)^{2}} \sqrt{\left(n \sum Y^{2}\right)-\left(\sum Y\right)^{2}}}
$$

Where,

$$
\begin{aligned}
& \mathrm{n}=\text { number of observation (year) } \\
& \mathrm{X}=\text { independent variable (Listed Companies/Securities) } \\
& \mathrm{Y}=\text { dependent variable (Traded Companies/Securities) }
\end{aligned}
$$

Ratio Analysis: This approach has been tested on Market Size and Market Liquidity to analyze development of capital market. To measure market size, Market Capitalization Ratio (MCR) is used. Market size is positively correlated with the ability to mobilize capital and diversity to risk on an economy- wide basis (Mishra et.al, 2010) resulting to development of capital market.

$$
M C R=\frac{\text { MarketCapitalization }}{G D P}
$$

To measure market liquidity (ML) shares of traded in the stock market is divided by GDP. Liquid capital market allows companies on the one hand, to have a permanent access to capital through equity issues and on the other hand to allow investors to switch out of equity (Mishra et.al, 2010) and ensuring their integrity as capital market development (Grais \& Vittas, 2005).

$$
M L=\frac{\text { AnnualTurnover }}{G D P}
$$


Growth Analysis: General growth formula has been used extensively to analyze growth in different NEPSE index. Development is the core aspect that can be measured by the growth as a whole (Gurung, 2004).

$$
\mathrm{A}_{\mathrm{t}}=\mathrm{A}_{0}\left(1+\mathrm{g}^{\mathrm{n}}\right)
$$

Where, $A_{t}=$ values at the end of the FY

$\mathrm{A}_{0=}$ value at the beginning of the FY

$\mathrm{n}=\mathrm{t}-1$, time period over which growth take place

$\mathrm{g}=$ growth rate

For this purpose different indicators of NEPSE index have been calculated, i.e. public issue and issue amount, number of transaction and annual turnover, paid up value and market capitalization and securities businesspersons etc.

Similarly, for primary data analysis, inferential analysis T-test is used to validate the association between independent variable and dependent variable.

\section{Data Analysis and Discussion}

\subsection{Secondary Capital Market}

Capital Market helps to flow of non-productive small savings spread among the people to the productive sector through mobilization. Capital Market establishes working relationships between the people engaged in saving, mobilization, and investing capital. A capital Market plays vital role in the economy as it mobilizes the unproductive financial resource in productive sectors of the economy (Nepal Rastra Bank, 2012).

Table 1: Secondary Market Analysis

\begin{tabular}{cccccc}
\hline Year & $\begin{array}{c}\text { Number of } \\
\text { Listed } \\
\text { Companies }\end{array}$ & $\begin{array}{c}\text { Number of } \\
\text { Listed } \\
\text { Securities (000') }\end{array}$ & $\begin{array}{c}\text { Share } \\
\text { Transaction } \\
\text { Value }\end{array}$ & $\begin{array}{c}\text { No. of Shares } \\
\text { Transacted } \\
\left(\mathbf{0 0 0}^{\prime}\right)\end{array}$ & $\begin{array}{c}\text { Number of } \\
\text { Transaction }\end{array}$ \\
\hline $2008 / 09$ & 159 & 30547.17 & 2168.11 & 209091 & 51293.9 \\
$2009 / 10$ & 176 & 26231.35 & 1185.11 & 213733 & 37687.13 \\
$2010 / 11$ & 209 & 26240.39 & 666.53 & 302364 & 32348.43 \\
$2011 / 12$ & 216 & 41878.9 & 1027.28 & 293489 & 36826.21 \\
$2012 / 13$ & 230 & 81571.7 & 2204.88 & 292366 & 51449.21 \\
$2013 / 14$ & 233 & 214143.6 & 7729.85 & 566389 & 105716 \\
$2014 / 15$ & 232 & 159717.5 & 6533.15 & 477278 & 98940.39 \\
$2015 / 16$ & 229 & 302021 & 16395.77 & 831997 & 189013 \\
$2016 / 17$ & 212 & 257329.1 & 13234.03 & 801095 & 153692.8 \\
\hline
\end{tabular}

Source: Nepal Stock Exchange Ltd.

The number of listed companies continued to increase until 2013/14 but after that it started to decline and reached 212 in the year 2016/17. Similarly, number of listed 
securities has a fluctuating trend. It continued to drop for 2 consecutive years till $2010 / 11$ but after that it continued to increase till 2013/14. Share transaction value continued to decrease and reached its lowest point (666.53) in 2010/11, but after that it gained its pace and continued to increase. The number of shares transacted and number of transaction both significantly increased in the year 2015/16.

\section{General Information of Capital Market}

The financial market information are very important part of the analysis because it varies from investor to investors but still it has certain pattern that helps in analyzing the investment decision.

Table 2: Capital Market Analysis

\begin{tabular}{|c|c|c|c|}
\hline Basis For Classification & Category & Frequency & Percentage \\
\hline \multirow[t]{4}{*}{ Financial Market } & Primary & 95 & 47.5 \\
\hline & Secondary & 27 & 13.5 \\
\hline & Both & 78 & 39.0 \\
\hline & Total & 200 & 100.0 \\
\hline \multirow[t]{6}{*}{ Duration of Investment } & Less Than 6 Month & 33 & 16.5 \\
\hline & Less Than A Year & 54 & 27.0 \\
\hline & $1-2$ Year & 37 & 18.5 \\
\hline & 2-5 Year & 15 & 7.5 \\
\hline & Above 5 Years & 61 & 30.5 \\
\hline & Total & 200 & 100.0 \\
\hline \multirow[t]{4}{*}{ Source of Investment } & Saving & 87 & 43.5 \\
\hline & Borrowing & 9 & 4.5 \\
\hline & Both & 104 & 52.0 \\
\hline & Total & 200 & 100.0 \\
\hline Size of Investment in & Below Rs.5,00,000 & 117 & 58.5 \\
\hline \multirow{5}{*}{ Terms of Market Value } & Rs. $5,00,000$ - Rs. $25,00,000$ & 62 & 31.0 \\
\hline & Rs, $25,00,001$ - Rs. $50,00,000$ & 6 & 3.0 \\
\hline & Rs. $50,00,001$ - Rs. $1,00,00,000$ & 12 & 6.0 \\
\hline & Above Rs. $1,00,00,000$ & 3 & 1.5 \\
\hline & Total & 200 & 100.0 \\
\hline
\end{tabular}

The majority of investors i.e. $30.5 \%$ hold their investment for more than 5 years and $27 \%$ hold it for less than a year. It implies that investors either like to hold for long term or for less than a year. The majority of respondents i.e. 52\% invests their saving as well as borrows the fund to invest in the stocks. $43.5 \%$ of the investors invest their saving in stock whereas only $4.5 \%$ investors borrow fund to invest in stocks. The majority of respondents i.e. $58.5 \%$ have investment worth below Rs $5,00,000$, whereas, only $1.5 \%$ of respondents have investment worth above Rs $1,00,00,000$. 


\subsection{Ratio and Growth Analysis of Nepalese Capital Market}

Market capitalization to GDP ratio (MCR) is a broad way to access the size of capital market and also helps to determine whether the market is overvalued or undervalued, compared to a historical average. It had a fluctuating trend during the study period and is below 100 . A ratio above $100 \%$ shows overvaluation and one below $50 \%$ shows that the market may be undervalued. Similarly, in last two fiscal years the ratio exceeded $50 \%$ which means the market is neither overvalued nor undervalued. It significantly increased from $46.4 \%$ to $84.1 \%$ from FY 2014/15 to FY 2015/16 due to rapid increment in the Market Capitalization. This ratio indicates the relative importance of stock market to the national economy and assumes that stock market size is positively correlated with the ability to mobilize capital and diversify risk. (KC, 2004).

Table 3: Market Size and Liquidity

\begin{tabular}{lccccc}
\hline Year & $\begin{array}{l}\text { GDP at Current } \\
\text { Price }\end{array}$ & $\begin{array}{l}\text { Market } \\
\text { Capitalization }\end{array}$ & Turnover & MCR & ML \\
\hline $2006 / 07$ & 727,827 & 186301 & 8360.1 & $25.6 \%$ & $1.1 \%$ \\
$2007 / 08$ & 815,658 & 366248 & 22820 & $44.9 \%$ & $2.8 \%$ \\
$2008 / 09$ & 988,272 & 512939 & 21681.14 & $51.9 \%$ & $2.2 \%$ \\
$2009 / 10$ & $1,192,774$ & 376871 & 11851.11 & $31.6 \%$ & $1.0 \%$ \\
$2010 / 11$ & $1,366,954$ & 323484 & 6665.33 & $23.7 \%$ & $0.5 \%$ \\
$2011 / 12$ & $1,527,344$ & 368260 & 10272.8 & $24.1 \%$ & $0.7 \%$ \\
$2012 / 13$ & $1,695,011$ & 514490 & 22048.8 & $30.4 \%$ & $1.3 \%$ \\
$2013 / 14$ & $1,964,540$ & 1057160 & 77298.5 & $53.8 \%$ & $3.9 \%$ \\
$2014 / 15$ & $2,130,150$ & 989400 & 65331.5 & $46.4 \%$ & $3.1 \%$ \\
$2015 / 16$ & $2,247,427$ & 1890130 & 163957.7 & $84.1 \%$ & $7.3 \%$ \\
$2016 / 17$ & $2,599,234$ & 1856830 & 132340.3 & $71.4 \%$ & $5.1 \%$ \\
\hline
\end{tabular}

Turnover is often used as a proxy for liquidity (Khan et al., 2015). In the past 10 FYs annual turnover in NEPSE has fluctuated between Rs.6665.33 million to Rs.163957.7 million. It significantly rose from Rs. 22048.8 million in FY 2012/13 to Rs. 77298.5 million in FY 2013/14. It reached its highest in the year 2015/16. It was due to full implementation of dematerialization system for share trading.

During 10 years study period, the value of shares traded accounted to GDP ratio (ML) reached lowest i.e. $0.5 \%$ in the year $2010 / 11$ whereas increased up to $7.3 \%$ in the year 2015/16. In countries with developed stock market this figure is as high as 40 percent and in many developing countries the values of shares traded vary in a range of 5 to 10 percent of gross domestic product. Low ratio of value of shares traded to gross domestic product indicates trading in equity to the size of economy is very low in Nepal. (KC, 2004). 
Table 4. Stock Market Growth in Nepal

\begin{tabular}{|c|c|c|c|c|c|c|c|c|c|c|c|c|}
\hline & \multicolumn{2}{|c|}{ Listed Securities } & \multicolumn{2}{|c|}{ Traded Securities } & \multicolumn{2}{|c|}{$\begin{array}{l}\text { Annual } \\
\text { Transaction }\end{array}$} & \multicolumn{2}{|c|}{ Annual Turnover } & \multicolumn{2}{|c|}{ Paid Up Value } & \multicolumn{2}{|c|}{$\begin{array}{l}\text { Market } \\
\text { Capitalization }\end{array}$} \\
\hline & Number & $\begin{array}{l}\text { Annual } \\
\text { Growth }\end{array}$ & Number & $\begin{array}{l}\text { Annual } \\
\text { Growth }\end{array}$ & Number & $\begin{array}{l}\text { Annual } \\
\text { Growth }\end{array}$ & Number & $\begin{array}{l}\text { Annual } \\
\text { Growth }\end{array}$ & Number & $\begin{array}{l}\text { Annual } \\
\text { Growth }\end{array}$ & Number & $\begin{array}{l}\text { Annual } \\
\text { Growth }\end{array}$ \\
\hline $2005 / 06$ & 226540 & - & 12221.93 & - & 97374 & - & 3451.4 & - & 19958 & - & 96763.7 & - \\
\hline 2006/07 & 243504 & $7 \%$ & 18147.25 & $48 \%$ & 120510 & $24 \%$ & 8360.1 & $142 \%$ & 21799 & $9 \%$ & 186301.13 & $93 \%$ \\
\hline 2007/08 & 321131 & $32 \%$ & 28599.77 & $58 \%$ & 150800 & $25 \%$ & 22820 & $173 \%$ & 29465 & $35 \%$ & 366247.5 & $97 \%$ \\
\hline 2008/09 & 637868 & $99 \%$ & 30547.16 & $7 \%$ & 209091 & $39 \%$ & 21681.14 & $-5 \%$ & 61140 & $108 \%$ & 512939.07 & $40 \%$ \\
\hline $2009 / 10$ & 821746 & $29 \%$ & 26231.35 & $-14 \%$ & 213733 & $2 \%$ & 11851.11 & $-45 \%$ & 79356 & $30 \%$ & 376871.37 & $-26 \%$ \\
\hline 2010/11 & 1033674 & $26 \%$ & 26240.39 & $0 \%$ & 302364 & $41 \%$ & 6665.33 & $-44 \%$ & 100238 & $26 \%$ & 323484.34 & $-15 \%$ \\
\hline 2011/12 & 1140081 & $10 \%$ & 41885.4 & $60 \%$ & 293489 & $-3 \%$ & 10272.8 & $54 \%$ & 110610 & $10 \%$ & 368260 & $14 \%$ \\
\hline 2012/13 & 1297841 & $14 \%$ & 81571.7 & $95 \%$ & 292366 & $0 \%$ & 22048.8 & $115 \%$ & 126490 & $14 \%$ & 514490 & $40 \%$ \\
\hline 2013/14 & 1468506 & $13 \%$ & 214143.6 & $163 \%$ & 566389 & $94 \%$ & 77298.5 & $251 \%$ & 142360 & $13 \%$ & 1057160 & $105 \%$ \\
\hline 2014/15 & 1631525 & $11 \%$ & 159717.5 & $-25 \%$ & 477278 & $-16 \%$ & 65331.5 & $-15 \%$ & 157580 & $11 \%$ & 989400 & $-6 \%$ \\
\hline 2015/16 & 2105437 & $29 \%$ & 302021 & $89 \%$ & 831997 & $74 \%$ & 163957.7 & $151 \%$ & 204020 & $29 \%$ & 1890130 & $91 \%$ \\
\hline 2016/17 & 2965884 & $41 \%$ & 392598.2 & $30 \%$ & 801095 & $-4 \%$ & 132340.3 & $-19 \%$ & 251590 & $23 \%$ & 1856830 & $-2 \%$ \\
\hline
\end{tabular}

The percentage of listed securities ranged from $7 \%$ to $41 \%$ during 10 years study period. Similarly, the overall growth rate of listed securities is $24 \%$. In the FY 2009/10, number of traded securities decrease from 30547.16 to 26231.35 leading to negative growth rate of $14 \%$. Once again in the year 2014/15, the growth rate of number of traded securities went negative i.e. $-25 \%$. The overall growth rate of traded securities is $34 \%$.

The number of annual transactions shows fluctuating trend during the study period. It has increased from around 97374 in the FY 2005/06 to 302364 in the FY $2010 / 11$ but in the next year it fell to 293489 . The highest growth rate i.e. $94 \%$ took place in 20013/14. However, the overall growth rate during the study period was $19 \%$. The increasing number of transactions implies the higher liquidity and attractiveness in securities but the overall growth rate is unsatisfactory.

Annual turnover in stock exchange has fluctuated between Rs.8360.1 million to Rs. 132340.3 million in the past 10 FYs. The overall growth rate of annual turnover is $36 \%$ over the observed period. Annual Turnover significantly decreased three FYs consecutively from $2008 / 09$ to $2010 / 11$, it indicates unattractiveness in securities, whereas, in the year 2015/16 the value reached highest i.e. Rs. 163957.7 million due to full implementation of dematerialization system. Despite numerous negative annual growth rate, the overall growth rate of annual turnover in the observed period is $36 \%$.

The amount of paid up capital has increased in every subsequent FYs. However, the annual growth rate has not increased in the same ratio. In the year 2008/09 the paid up value reached its maximum of Rs. 61140 million with annual growth rate of $108 \%$. The overall growth rate of Paid up capital is $24 \%$.

The market capitalization is based on closing market price of listed securities. The trend of market capitalization is fluctuating and even had negative annual growth 
rate in the year 2009/10,2010/11, 2014/15 and 2016/17. Even though, overall growth rate of the market capitalization during the study period is $28 \%$ which signifies development in capital market but the development is not satisfactory.

\section{Correlation Analysis}

Karl Pearson's Correlation Coefficient ( $\mathrm{r}$ ) and test significance between traded and listed companies were accessed. Karl Pearson's Correlation Coefficient (r) between traded and listed companies is 0.916815 . It implies that they are highly positively correlated. The test statistics value $(6.494046)>\mathrm{T}$-value (2.365) so there is significant relationship between the variables.

\section{Table 5: Correlation Analysis}

\begin{tabular}{|l|l|l|l|}
\hline Karl Pearson's Correlation Coefficient & r & Test statistics & T-values \\
\cline { 2 - 4 } & 0.916815 & 6.494046 & 2.365 \\
\hline
\end{tabular}

\subsection{T-test Analysis}

Test value is used to signify the importance between variables. In this research, Test value is used to signify the importance between investment decision and various aspects and factors. The table shows the T-test Analysis of Factors Influencing Investment Behavior to study significance of various factors for Investment Decision.

Table 6: T-test Analysis of Factors Influencing Investment Decision

\begin{tabular}{|c|c|c|c|c|c|c|}
\hline Statements & $\mathbf{N}$ & Mean & $\begin{array}{l}\text { Std. } \\
\text { Dev }\end{array}$ & $\begin{array}{l}\text { T- } \\
\text { Value } \\
\end{array}$ & $\begin{array}{l}\text { Sig. (2- } \\
\text { Tailed) }\end{array}$ & Remarks \\
\hline \multicolumn{7}{|c|}{ Advocate Recommendation (H01) } \\
\hline Family Member's Opinion & 200 & 3.61 & 1.23 & 41.40 & 0.00 & Significant \\
\hline Broker's Recommendation & 200 & 3.59 & 0.99 & 51.37 & 0.00 & Significant \\
\hline $\begin{array}{l}\text { Opinion Of Firm's Majority } \\
\text { Stockholder }\end{array}$ & 200 & 4.01 & 1.10 & 51.68 & 0.00 & Significant \\
\hline Friend's Opinion & 200 & 3.64 & 1.22 & 42.27 & 0.00 & Significant \\
\hline $\begin{array}{l}\text { Personal Financial Needs (H02) } \\
\text { Ease Of Obtaining Borrowed } \\
\text { Funds }\end{array}$ & 200 & 3.25 & 0.50 & 92.49 & 0.00 & Significant \\
\hline $\begin{array}{l}\text { Expected Losses In International } \\
\text { Financial Markets }\end{array}$ & 200 & 3.15 & 0.39 & 113.06 & 0.00 & Significant \\
\hline $\begin{array}{l}\text { Expected Losses In Other Local } \\
\text { Investments }\end{array}$ & 200 & 3.34 & 0.47 & 99.46 & 0.00 & Significant \\
\hline $\begin{array}{l}\text { Minimize Risk } \\
\text { Accounting Information (H03) }\end{array}$ & 200 & 3.42 & 0.63 & 76.90 & 0.00 & Significant \\
\hline Expected Corporate Earnings. & 200 & 3.72 & 0.72 & 72.66 & 0.00 & Significant \\
\hline Expected Dividend & 200 & 3.69 & 0.78 & 66.79 & 0.00 & Significant \\
\hline
\end{tabular}




\begin{tabular}{|c|c|c|c|c|c|c|}
\hline Dividend Paid In The Past & 200 & 3.38 & 0.97 & 48.99 & 0.00 & Significant \\
\hline Past Performance Of the Stock & 200 & 3.91 & 0.95 & 57.87 & 0.00 & Significant \\
\hline Affordability Of Share Price & 200 & 3.62 & 0.88 & 58.24 & 0.00 & Significant \\
\hline Condition Of Financial & 200 & 3.56 & 0.79 & 63.45 & 0.00 & Significant \\
\hline \multicolumn{7}{|l|}{ Statement } \\
\hline \multicolumn{7}{|l|}{ Firm's Image (H04) } \\
\hline Firm's Reputation In Industry & 200 & 4.15 & 0.95 & 61.80 & 0.00 & Significant \\
\hline Firms Perceived Ethics. & 200 & 3.50 & 1.11 & 44.64 & 0.00 & Significant \\
\hline $\begin{array}{l}\text { Feelings For Firm's Product / } \\
\text { Service }\end{array}$ & 200 & 3.32 & 1.25 & 37.53 & 0.00 & Significant \\
\hline Get Rich Quick & 200 & 3.08 & 0.58 & 74.46 & 0.00 & Significant \\
\hline Reputation Of Firm's & 200 & 3.34 & 0.62 & 75.99 & 0.00 & Significant \\
\hline Shareholder & & & & & & \\
\hline Solving Community Problems & 200 & 3.03 & 0.67 & 63.78 & 0.00 & Significant \\
\hline Firm Status In Industry & 200 & 3.65 & 0.89 & 58.02 & 0.00 & Significant \\
\hline Neutral Information (H05) & & & & & & \\
\hline $\begin{array}{l}\text { Current Economic Factors Like } \\
\text { Inflation, Interest Rate etc. }\end{array}$ & 200 & 3.43 & 0.76 & 63.80 & 0.00 & Significant \\
\hline $\begin{array}{l}\text { Statement From Government } \\
\text { Officials }\end{array}$ & 200 & 3.50 & 0.74 & 66.48 & 0.00 & Significant \\
\hline Coverage In The Press & 200 & 3.51 & 0.76 & 64.92 & 0.00 & Significant \\
\hline
\end{tabular}

Various statements are provided to analyze the significance of investment decision and the factors affecting it. All the hypotheses have significant association. The detail analysis of the hypothesis test has been mentioned in Appendix 2.

\section{Concluding Remarks}

Capital market and financial institutions are the source of development of any economy. Developed economics have fully developed capital market, whereas underdeveloped economies usually have premature capital market that consists of very few financial instruments. Nepal lags behind to develop a healthy capital market although it remains important for all types of investors. Nepalese capital market has a very long way to go but we cannot ignore the recent development and advancement in technology and process improvement.

Market has been deepening with increased listed companies and traded companies every year. The erratic trend in the value of market capitalization imply poor and immature capital market, de-motivation in investment in the companies, and downward trend of economy during the study period. The total no. of listed shares is in increasing trend which is a good signal for the financial market and for the economy as a whole. It increases the transparency and reduces the risk of fraud as well as strengthens the financial system. Increase in number of listed companies and shares also represent growth of Nepalese securities market. In spite of the 
significant relationship between traded and listed companies, the number of companies traded is not satisfactory during the study period. These evidences indicate the trading of securities is unattractive and this also implies that there is lack of confidence among investors and uncertainty in the investment environment in the economy.

Similarly, Market capitalization to GDP ratio had a fluctuating trend during the study period and was below $100 \%$. It means the Nepalese market is neither overvalued nor undervalued but there are lots of spaces for improvement. The fluctuating trend also signifies that the market is still in growth phase. The value of shares traded accounted to GDP ratio vary in range of 0.5 to 7.3 percent of gross domestic product. In many developing countries the values of shares traded vary in a range of 5 to 10 percent of gross domestic product. Low ratio of value of shares traded to gross domestic product indicates trading in equity to the size of economy is very low in Nepal.

Therefore, ratios used to measure the market size and the liquidity has provided the acceptable ratio in developing country. The entire indicator used in this study to measure growth has provided positive indication. On the basis of these outcomes, it has been concluded that Nepalese capital market has developed since 2005/06. This argument has been supported by gradual infrastructure improvements in primary and secondary market, i.e. CDS and mutual funds.

The growing secondary market definitely yields higher return and this higher return would induce new investors to invest in share market. This statement is supported by the growth rate of Annul Transaction and Annual Turnover. Hence, there is no doubt that development and growth in capital market attract new investors but at the same time these investors consider various influencing factors before investing in the market.

The findings suggest that most influencing factors in investment decision making is reputation of the firm. The investors are assumed to focus on get rich quick notion but the data revealed that they are least influenced by it. It implies that investors are not aware about the speculative gain they can earn by grabbing the opportunity. The finding confirms that the trust of investors on broker recommendation is very limited. It implies that investors are well aware that stock brokers can easily manipulate them if they blindly rely on their recommendations while making investment decisions.

Investors assume that the majority of stockholders have knowledge and information about the company and therefore their investment decision is strongly affected by their opinion. Similarly, their investment decisions are also influenced by their family and friends' opinion. Instead of relying completely on broker's 
recommendation, their investment decisions are also influenced by their family and friends' opinion as well. The investors value the information received from the press, statement from government officials which educate the investors about the real scenario and prevents the investors from investing in weak institutions. Investors not only invest to earn higher return but also invest to minimize the risk. It proves that they have some knowledge about financial diversification and it is due to their higher education. The investment decisions are not solely based on position of financial statement and most of times their decisions depend on the firm's reputation, opinion of majority of stakeholder and status of the firm. This shows that investors can earn profit with the help of fundamental analysis. Also, the investors are assumed to be a rational investor but they are highly affected by their ages.

Stock exchanges should try to disseminate as much timely public information as possible on corporate financial performance, which will stabilize any speculative trends in the market. It should come with strict policies regarding transparency in investment value chain to prevent stock market crisis.

It is also recommended to focus on statement from government officials too because such statement are meant to it aware the investors regarding real performance of the stock. Investors should acquire fundamental analysis skills in order to compare market value and book value of the company. Investors should also diversify their investment in different companies by developing a portfolio of investments to minimize risks and maximize returns.

\section{References}

Abdeldayem, M.M. (2016). Is there a relationship between financial literacy and investment decisions in the Kingdom of Bahrain? Management and Administrative Science Review, 5(4), 203 - 221.

Adhikari, P. (2010). Investment behavior of Nepalese Investors. Journal of Management, $3(1), 12-20$.

Akhbar, M., Salman, A., Mugal, S. K., \& Mehmood, F. (2016). Factors affecting the individual decision making: A case study of Islamabad stock exchange. European Journal of Economic Studies, 15, 242-258.

Akingbohungbe, S. S. (1996). The role of the financial sector in the development of the Nigerian economy. Centre for Africa Law and Development Studies, 46.

Al-Tamimi, H. H. (2006). Factors influencing individual investor behaviour: An empirical study of the UAE financial markets. Journal of Business and Management, 1(2), 1-21.

Baker, M. \& Wurgler, J.(2006).Investor sentiment and the cross-section of stock returns. Journal of Finance, 4(12), 304-343 
Bashir, D., Aaqiba Javed, Butt, A. A., Azam, N., Tanveer, A., \& Ansar, I. (2013). An assessment study on the factors influencing the individual. Journal of Business and Management, 37-44.

Bist, J. P. (2017). Stock Market Development and Economic Growth in Nepal: An ARDL Representation. Journal of Finance and Economics, 5(4), 164-170.

Blackburn, K., Bose, N. and Capasso, S. (2005). Financial development, financial choice and economic growth", Review of Development Economics, 9 (2), 135-149.

Dharmaja, G., V, Ganesh. J, Dr. Santhi. V. (2012). A Study on the Individual Investor Behavior with Special Referance to Geojit BNP Paribas Financial Service Ltd, Coimbatore. IRACST-International Journal of Research in Management \& Technology (IJRMT), 2(2), 243-252.

El-Wassal. (2013). The development of stock markets: In search of a theory. International Journal of Economics and Financial Issues, 3(3), 606-624.

Gurung, J. B. (2004). Growth and performance of securities market in Nepal. Journal of Nepalese Business Studies, 1(1), 85-92

Hoque, M. E., \&Yakob, N. A. (2017).Revisiting stock market development and economic growth nexus: The moderating role of foreign capital inflows and exchange rates. Cogent Economics and Finance, 6(1), 1329975.

Jagongo, A., Mutswenje, V.S. (2014). A survey of the factors influencing investment decisions: The case of individual investors at Nairobi stock exchange. Journal of Business and Management, 4(10), 20-22.

K.C., Bijaya. 2004. Development of Stock Market and Economic Growth in Nepal. Journal $1,25-37$

Kadariya, S. (2012). Factors affecting investor decision making: A case of Nepalese capital market. Journal of Research in Economics and International Finance, 1(1), 16-30.

Khan, F., Afrin, F., \& Rahman , M. A. (2015). Factors Influencing Investors' decisions in Stock Market. Journal of Finance and Accounting, 198-204.

Lodhi, S. (2014). Factors influencing individual investor behavior: An empirical study of city Karachi. Journal of Business and Management, 16(2), 68-76.

Merikas, A. A., Merikas, A. G., Vozikis, G. S., \& Prasad, D. (2008). Economic factors and individual investor behavior: The case of the Greek stock exchange. Journal of Applied Business Research, 20(4), 4-6.

Mishkin. F. S. \& Eakins. S.G. 2012. Financial Markets \& Institutions (7th eds.). Boston: Prentice Hall.

Mishra, P.K. et al., 2010. Performance of Indian Capital Market - An Empirical Analysis. European Journal of Economics, Finance, and Administrative Sciences, 23(23), $49-57$.

Nepal Rastra Bank (2012). Annual Report 2010-11. Kathmandu: Nepal Rastra bank. 
NEPSE (2005/06- 2016/17). Annual Report. Kathmandu, Nepal Stock Exchange Ltd.

Obamuyi, T. M. (2013). Factors influencing investment decisions in capital market: A study of individual investors in Nigeria. Journal of Economics and Management, 4(1), 30-89.

Obiakor, R.T. \& Okwu, A.T. (2011).Empirical Analysis of Impact of Capital Market Development on Nigeria's Economic Growth 1981-2008, Case Study: Nigerian Stock Exchange: DLSU Business \& Economies Review, 20(2), 76-96.

Raghuram, R. \& Luigi, Z. (2003). The great reversals: The politics of financial development in the twentieth century. Journal of Financial Economics, 69(1), 5-50

Safi, M. (2014). Determinants influencing individual investor behavior in stock market: A cross country research survey. Journal of Business and Management, 2(1), 60-71.

SEBON (2017). Annual Report (2005/06 - 2017/16). Kathmandu, Security Board of Nepal

UNCTAD (2011). The Least Developed Countries Report: The Potential Role of SouthSouth Cooperation for Inclusive and Sustainable Development United Nation. Geneva: United Nations Conference on Trade and Development.

Vijaya, E. (2014). Influential factors on investment behavior of individual investors: A review of empirical evidences from various countries. International Research Journal of Management and Commerce, 1(5), 35-46.

Wafik G., Dimitri, V. (2005). Institutional Investors, Contractual Savings and Capital Market Development. in Egypt, Jordan, Morocco, and Tunisia. In Neaime and Colton (Eds.) Money and Finance in the Middle East: Missed Opportunities or Future Prospects? Research in Middle East Economics, Volume 6 pp.43 - 65. London: Emerald Group Publishing Limited. 